\title{
Upstream migration and marine early life history of amphidromous gobies inferred from otolith increments and microchemistry
}

\author{
Jen-Chieh Shiao • Chyng-Shyan Tzeng • \\ Pi-Chiang Li • Kim N. I. Bell
}

Received: 30 January 2014 / Accepted: 28 July 2014 / Published online: 2 August 2014

C) Springer Science+Business Media Dordrecht 2014

\begin{abstract}
Amphidromous gobies are circumtropically distributed in mountainous coasts typical of volcanic islands. More than nine goby species recruit seasonally from the Pacific coasts to the Hsuikuluan River estuary eastern Taiwan from the spring to the summer. Using two seasons of field observations and sample collections, we explore the recruitment of amphidromous gobies from the Pacific Ocean into the Hsuikuluan River and their upstream migratory behaviors from the estuary to the lower reaches of the river. A metamorphosis check in the otolith which corresponds to the drop of $\mathrm{Sr} / \mathrm{Ca}$ ratios from higher $>4 \times 10^{-3}$ to lower levels $<4 \times$ $10^{-3}$ is found in most species after recruitment to fresh waters. The marine and freshwater stages for these goby species can therefore be confirmed from otolith microstructure and $\mathrm{Sr} / \mathrm{Ca}$ ratio analysis, and age in days of
\end{abstract}

J.-C. Shiao $(\bowtie)$

Institute of Oceanography, National Taiwan University,

No. 1, Sec. 4, Roosevelt Rd, Taipei 106, Republic Of China

e-mail: jcshiao@ntu.edu.tw

C.-S. Tzeng

Department of Life Science, National Tsing Hua University, No. 101, Sec. 2, Kuang-Fu Rd., Hsinchu, Taiwan 300,

Republic Of China

P.-C. Li

Department of Statistics, Feng Chia University, No. 100, Wenhwa Rd., Seatwen Taichung, Taiwan 40724, Republic Of China

K. N. I. Bell

Biology Department, Memorial University,

St. John's, NL A1B3X9, Canada these gobies is estimated from otolith daily increments. Rhinogobius gigas recruits to the estuary at 30-40 days after hatching, while the marine planktonic stage ranged from approximately 2-7 months for Awaous melanocephalus, Eleotris fusca, Glossogobius aureus, Sicyopterus japonicus (Tanaka, 1909), Stenogobius genivittatus, and Stiphodon elegans (Steindachner, 1879). The catch data from an artisanal fish trap show lunar and semi-lunar periodicity for the upstream migration of R. gigas and S. japonicus after a brief stay in the estuary. These two species accounted for more than $99 \%$ of the upstream migratory gobies collected in the fish trap. The short marine larval stage and presumed retention at the inshore area help to explain the endemism of $R$. giga. In contrast, $S$. japonicus has a lengthy marine stage of 6-7 months, which obviously could allow dispersal over a wide geographic range.

Keywords Fish larvae - Migrations · Lunar cycles

Otoliths $\cdot$ Endemism

\section{Introduction}

Artisanal fisheries for postlarval amphidromous gobies exist circumtropically and occasionally subtropically worldwide, though they are generally poorly documented or understood (Bell 1999). Management and conservation require a basis in knowledge of the species sustaining them, their life histories, and their requirements in each environment they inhabit through their life cycle. That knowledge 
is needed so that possible changes, whether due to global climate change or anthropogenic degradation, in those environments can be used to anticipate future or past changes in those fisheries' yields. This paper documents one such fishery in eastern Taiwan for the first time, exploring the species that sustain it and their dependence on the marine and river environments.

The amphidromous life history (Myers 1949; McDowall 2007) is found in phyletically diverse groups: many freshwater gobies, crustaceans, and some molluscs that occur circumtropically worldwide in island and continental coasts. The postlarvae return amphidromous life history involves adults spawning in fresh waters (Maeda et al. 2008); larvae migrating by stream drift to the sea (Iida et al. 2010); postlarvae returning to rivers and developing into juveniles (Iida et al. 2008) and then iteroparous adults that never return to the sea (Takahashi and Yanagisawa 1999). Typically, small (e.g., $0.5 \mathrm{~mm}$ ) adhesive eggs on the underside of rocks or other structures in the river (Manacop 1953; Bell and Brown 1995, for sicydiine gobies; Foster and Fuiman 1987 for Evorthodus), with active broodcare by the male and rapid (1-2 d) hatching. A female can repeat spawn within 2 weeks with strong implications for lifetime fecundity (Takahashi and Yanagisawa 1999). Newly-hatched larvae lack an inflated airsac and therefore use active swimming to remain in the water column to drift to the sea and later select a salinity layer (Bell and Brown 1995), and this is consistent with behaviour previously observed in vertically invariant salinities by Manacop (1953) and Foster and Fuiman (1987). Caribbean Sicydium punctatum (Perugia, 1896) larvae during $0-5$ days post hatching actively minimize their exposure to salinities $>10 \mathrm{ppt}$ in haloclines, but then occupy increasingly saline water (Bell and Brown 1995), and similar results were found for a Pacific species Sicyopterus japonicus (Tanaka, 1909) (Iida et al. 2010). After the marine planktonic stage, gobies return to the river mouth as post-larvae and ascend the river as early-juveniles (Iida et al. 2008; Lord et al. 2010).

Post-larval amphidromous gobies' seasonality of recruitment to estuaries varies across latitudes. There is year-round recruitment in tropical areas e.g., for Sicyopterus lagocephalus (Pallas, 1770) in Philippines (Manacop 1953), La Réunion Island (Teichert et al.
2014), Sicydium punctatum in Dominica (Bell et al. 1995) and Lentipes concolor (Gill, 1860) in Hawaii (Kinzie 1993; Radtke et al. 2001), with seasonally delimited recruitment in subtropical areas, as for S. lagocephalus in Réunion (Bielsa et al. 2003), and the shortest known seasonal recruiting period is in temperate latitudes, for Sicyopterus japonicus in Japan (Iida et al. 2008). The marine larval duration of amphidromous gobies varies greatly, from about 2 months to more than 6 months depending on the species (e.g., Hoareau et al. 2007; Iida et al. 2008; Lord et al. 2010).

In some areas, the biomass of upstream migrating gobies has been substantial and important in human nutrition (Manacop 1953). Although declines of gobyfry (i.e. larval to juvenile stage) fishery had been reported globally (Bell 1999), biological and fishery data were usually insufficient for effective fishery management and species conservation. For example, amphidromous gobies have long been harvested by aborigines in eastern Taiwan according to an anthropological study (Yuan 1969). Little is known of the fisheries, biology and ecology of these exploited gobies. Here we investigate age at recruitment, and migratory behaviors, and species composition in the fishery.

Otoliths are biomineral structures inside the otic vesicles of teleost fish, and are part of the balance and auditory systems. The periodic increments in the otolith provide a means of determining age, and increment width changes can be associated with important life history events such as hatching and metamorphosis (e.g., Campana 2005). Fishes can absorb $\mathrm{Sr}$ in the ambient water and substitute for $\mathrm{Ca}$ in the process of $\mathrm{CaCO}_{3}$ deposition in the otolith. Otolith elemental compositions such as $\mathrm{Sr} / \mathrm{Ca}$ ratio naturally mark periods of freshwater (i.e., low $\mathrm{Sr} / \mathrm{Ca}$ ratio) and seawater (i.e., high $\mathrm{Sr} / \mathrm{Ca}$ ratio) residence (Gillanders 2005). Therefore, otolith microstructure and microchemistry have been used to reveal the occupancy pattern of many amphidromous species (e.g., Shiao et al. 2006; Tabouret et al. 2010; Lord et al. 2011; Chang and Iizuka 2012).

In the Hsuikuluan River estuary of eastern Taiwan, the gobies were fished at the translucent post-larval stages when they were entering the river mouth and caught at the early juvenile stage migrating further upstream by a traditional artisanal fish trap. Translucent post-larvae were traditionally fished in the surf zone near the river mouth around the new moon and full moon between early spring and summer; both seasonal 
and lunar periodicities in recruitment are known in similar species elsewhere (Bell et al. 1995; Shen and Tzeng 2008). This tradition suggested both seasonality and lunar/semi-lunar periodicity of the post-larval gobies. This interpretation, based on observations of fishermen's activities without further sampling, assumes that the fishery seasonality has been developed to conform to recruitment seasonality.

There were several purposes in this study. Firstly, we aimed to clarify the species involved and their recruitment periodicity. Secondly, the total catch of the gobies was evaluated from catch records in the spring-summer of 2 years using a unique traditional fish trap designed by the Amis aboriginal people to specifically catch upstream migrating gobies in the lower reaches of the Hsuikuluan River. Thirdly, the early migratory life history was revealed for each species by otolith microstructure and $\mathrm{Sr} / \mathrm{Ca}$ ratio analysis. The knowledge of life-history traits of the migratory gobies may provide further insight into the understanding of endemism or cosmopolitan distribution and relative dominance of each species in the river. The biological and fishery data reported in this study will be useful for further species conservation.

\section{Materials and methods}

\section{Sampling area}

The Hsiukuluan River is the largest river in eastern Taiwan, with a length of about $104 \mathrm{~km}$ and a drainage area of $1,790 \mathrm{~km}^{2}$. The width of the river is about $20-30 \mathrm{~m}$ in the lower reaches and becomes hundreds of meters at the estuary (Fig. 1), which is separated from the Pacific Ocean by a barrier island and sand berm. The estuary is connected to the Pacific Ocean by a narrow entrance channel about $20 \mathrm{~m}$ long and about $3-5 \mathrm{~m}$ in width. The local tidal range is approximately $0.5-0.8 \mathrm{~m}$ and the sea level at high tide is still lower than the top of the sand bern. Therefore, the estuary is subjected to only a very minor tidal influence and seawater can only invade the entrance channel, but not the estuary at a high spring tide. So the estuary is not a typical brackish environment, but is fresh water instead.
Current velocity was measured with a current meter (DENTAN, CM-1BN) or a portable meter (YOKOGAWA MODEL 3631). Water temperature in the lower reaches was collected hourly from December 1996 to August 1997 with a temperature data logger (ONSET Stowaway) set near the shore about $1 \mathrm{~km}$ from the coast.

Fish collection

Gobies in different developmental stages were collected at 2 locations i.e., the surf zone and upper estuary (Fig. 1). We defined the post-larval goby as translucent body without pigmentations on the fish body and the caudal fin remained forked end. Translucent post-larval gobies were only collected during freshwater recruitment in the surf zone. Upstream migratory gobies with partial pigmentation were defined as early juvenile stage and fully development of body pigmentation with rounded end of the caudal fin were regarded as juvenile or young stage. These definitions of developmental stages of the gobies were similar to previous study such as Keith et al. (2008). Only the early juvenile to young stags of the gobies were collected in a fish trap (Fig. 1, Fig. 2) operated by the Amis aboriginal people of the area. Translucent post-larvae of Rhinogobius gigas (Aonuma and Chen 1996) collected in the surf zone were purchased from the local fishermen from February to June 1995 and from February to June 1997 and their age at freshwater recruitment was determined by otolith daily growth increments. The Amis aborigines only caught the larval gobies in the surf zone of the estuary during the spring tide period (i.e., the days around the new moon and full moon) according to the interviews with local residents as well as our field observations over 2 years. By using the same fishing gear, a triangle hand-net as shown in Fig. 2a, we tried several times to collect the post-larval goby at night from February to May in 1996 during the neap tide period, but no goby fry could be found.

We obtained samples from the Amis people's fish trap (Fig. 1, Fig. 2b-f) from February-June in 1996 and from January-May in 1997. The design of the fish trap is clearly based on their understanding of the rheotaxis of the upstream-migrating gobies (Smith and Smith 1998). This trap was located at the lower reaches adjacent to the estuary, which was about $3 \mathrm{~km}$ away from the surf zone at the river mouth (Fig. 1, Fig. 2b-f). At this location Rhinogobius gigas and Sicyopterus japonicus were at a 

translucent post-larval gobies $(\bullet)$ in the surf zone near the river mouth and for pigmented early juvenile or young gobies ( $\mathbf{a})$ in the lower reach of the Hsiukuluan River, eastern Taiwan
Fig. 1 Sampling sites for

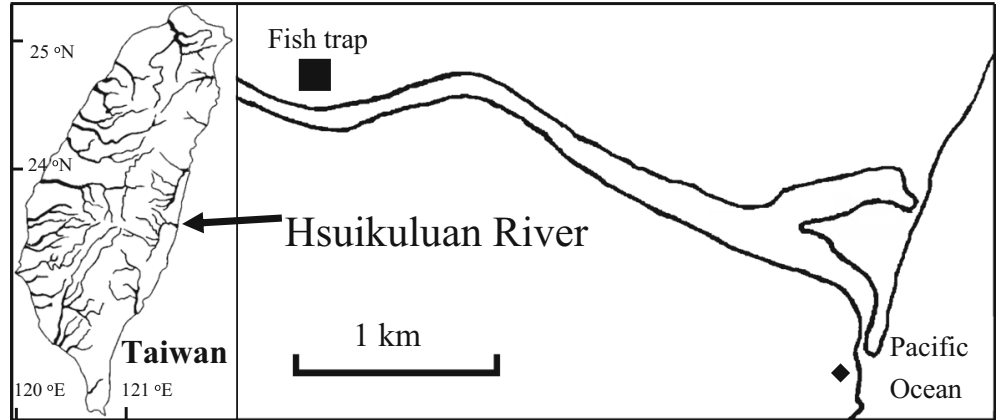

The fish trap was constructed of river stones,

partially-pigmened juvenile stage, but other species e.g., Awaous melanocephalus (Bleeker, 1849), Eleotris fusca (Forster, 1801), and Glossogobius aureus (Akihito et al. 2000) were at young to adult stage. timber, and other materials, and was installed at the edge of a reach where the current speed was fast (torrential, usually $>0.8 \mathrm{~m} \mathrm{sec}^{-1}$ ). The fisherman
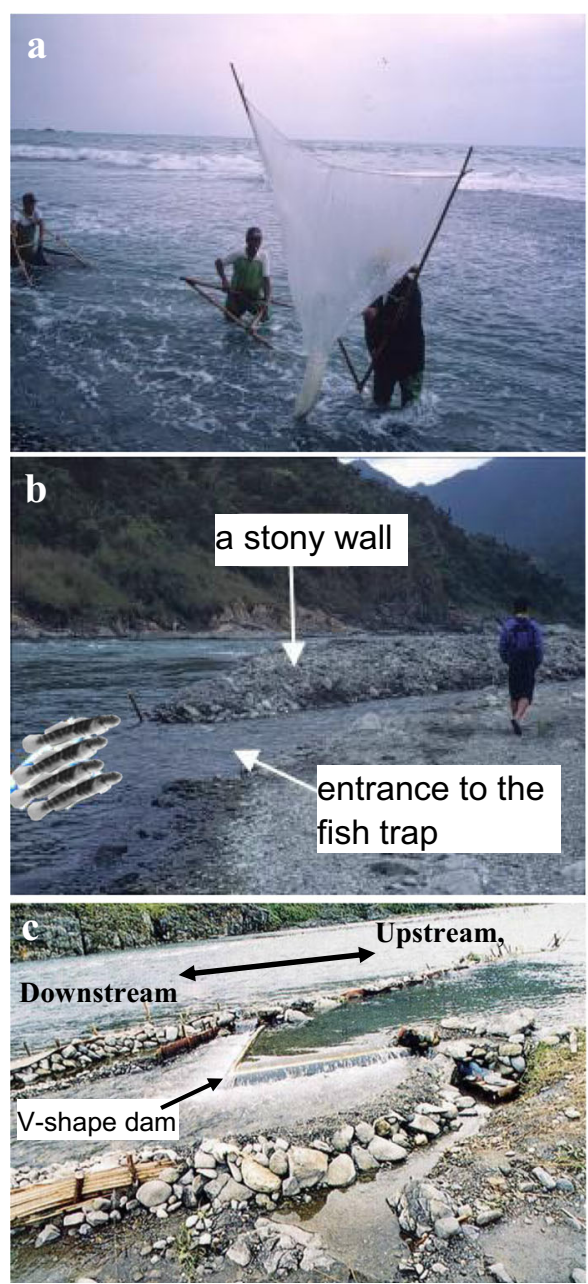

Fig. 2 Traditional fishing gear (panel a) used to collect translucent post-larval gobies in the surf zone near the Hsiukuluan River mouth and the fish trap (panels $b-f$ ) constructed by Amis

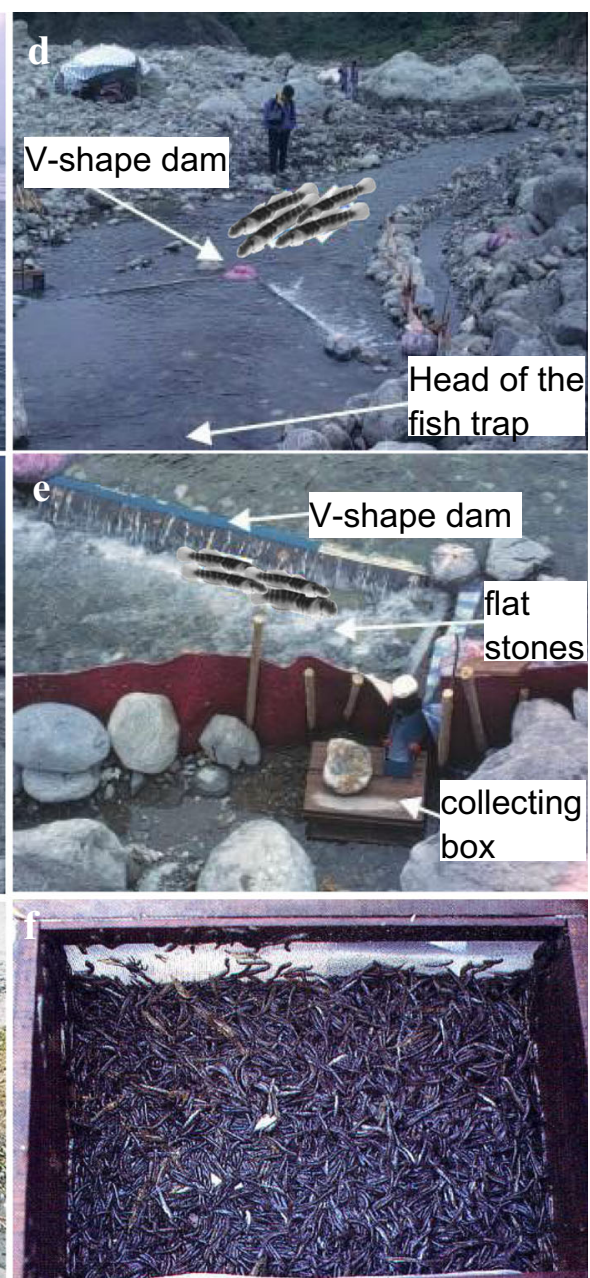

aborigines used to collect the pigmented early juveniles during upstream migration at the river side. The gobies were not drew to the scale 
first constructed a secondary, artificial, fish passage about $40 \mathrm{~m}$ long, separated from the main part of the river by a stony ridge of sand, stones, wooden and plastic materials to prevent water leaking into the passage from the river. A water level of $20-30 \mathrm{~cm}$ with a current velocity of $0.2-0.4 \mathrm{~m} \mathrm{sec}^{-1}$ was maintained in the fish passage by controlling the water volume into the fish passage from the upper end connected to the river. The slower current velocity attracts migratory gobies into the artificial fish passage because in higher currents the gobies migrate preferentially near the banks. This preferential behavior was observed and video recorded by snorkel diving (personal observation). At the upstreamend of the fish passage was a "V" shape dam (Fig. 2c-d) with a free fall about $30 \mathrm{~cm}$ in height to impede the upstream migration of the gobies and redirect the fish to the upper ends of the "V" shape dam where a wooden pipe was set (Fig. 2e). In front of the pipe, the streambed was covered by flat stones. Most water flowed through the "V" shape dam and less water flowed through the pipe and the flat stones. When the gobies reached this area, they moved forward by pectoral and ventral fin movements and eventually into the wooden pipe that channeled the fish into a collecting box (Fig. 2e-f). The local fishermen usually began operating the fish trap in early February when the recruiting season begins. The trap is operated continuously until it is destroyed by the seasonal heavy rains in April to May or by typhoons in June to August, making migration intensity data unavailable after late June in 1996 and early May in 1997. However, the upstream migration of the gobies still continued after the fish trap were destroyed based on the field observation along the river bank.

The collecting box was emptied and the catches weighed every day. Subsamples of $600 \mathrm{~g}$ were randomly taken from the catch and were preserved in $95 \%$ ethanol after April 14th in 1996 and during the whole fishing season in 1997. Because each fish weighs a fraction of a gram, $600 \mathrm{~g}$ is numerically a substantial sample. Species were identified according to the illustrated handbooks (Tzeng 1986a; Shen et al. 1993) and published papers (Tzeng 1986b; Chen et al. 1995; Chen and Shao 1996). The total fish count for each species was estimated as follows:

Total count species ${ }_{[i]}$ in catch $=$ count of fish of species [i] in $600 \mathrm{~g}$ subsample $\times$ total catch weight $(\mathrm{kg}) / 0.6$
To estimate migration speed, we followed a group of upstream migratory gobies (mostly Sicyopterus japonicus) along the riverside for $53 \mathrm{~min}$. A measuring tape was used to determine the distance from the beginning to the end of the observation. The behaviors of the gobies were also recorded by a CCD video camera under the water. To understand the daily migratory cycle, the gobies trapped in the collecting box were identified by species and the numbers were counted every $2 \mathrm{~h}$ on the following nine survey days: March 19, April 3, 8, 16, 22, May 7, 21, 27 and June 2 in 1996. Data on tidal ranges that were recorded in Hua-Lian Harbor about $70 \mathrm{~km}$ north of the Hsuikuluan River estuary were assumed to also apply to the Hsuikuluan River estuary.

\section{Otolith preparation and microprobe analysis}

Validation of otolith daily growth increment was done only for $R$. gigas. Thirty juvenile $R$. gigas caught in the fish trap in July 1996 were taken to the laboratory and reared in a $10 \mathrm{~L}$ tank with $350 \mathrm{mg}^{-1}$ tetracycline solution for 6 hours. About 10 gobies died during the immersion in tetracycline solution; the surviving gobies were moved to clear freshwater and were fully fed once a day with frozen Tubifex hattai. On the 20th day in captivity, the saggital otoliths were removed from the gobies to count the newly deposited growth increments during the experimental stage. A fluorescence microscope with incident light from a $50-\mathrm{W}$ mercury lamp was utilized to reveal the tetracycline fluorescent band on the ground surface of treated otoliths. The excitation wavelength of the incident light was limited by a band-pass filter (400-440 nm) and the emission wavelength was limited by a longpass barrier filter $(470 \mathrm{~nm})$.

The otolith $\mathrm{Sr} / \mathrm{Ca}$ ratios and otolith microstructure were used to distinguish the marine larval stage and estuarine/river period of $R$. gigas and some other species. Our a priori assumption was that oceanic exposure, and therefore the marine larval stage, would be represented by the otolith portion with higher $\mathrm{Sr} / \mathrm{Ca}$ ratios, while freshwater exposure, and the river stage would be indicated by lower $\mathrm{Sr} / \mathrm{Ca}$ ratios (e.g., Shen et al. 1998). Total lengths (TL) were measured to the nearest 
$0.05 \mathrm{~mm}$ with calipers and sagittal otoliths were dissected out under a stereo microscope, cleaned with distilled water, dried in air, and embedded in LR White ${ }^{\mathrm{TM}}$ resin. Embedded otoliths were ground until the primordium was exposed. The ground otoliths were polished with abrasive cloth and $0.05 \mu \mathrm{m}$ alumina solution until suitable for electron probe analysis (EPMA JEOL JXA $8800 \mathrm{M})$. The polished otoliths were coated with a thin layer of carbon to reduce X-ray diffraction and to increase electron conductance. $\mathrm{SrTiO}_{4}$ and $\mathrm{CaSiO}_{3}$ were used as the standards for $\mathrm{Sr}$ and $\mathrm{Ca}$ quantitative analysis. The electron acceleration voltage was $15 \mathrm{kV}$ and the probe current was $4 \mathrm{nA}$. The electron beam was focused on an area approximately $1 \mu \mathrm{m}$ in diameter at intervals of $5 \mu \mathrm{m}$ or $10 \mu \mathrm{m}$ between the otolith core and edge. For the X-ray intensity mapping of $\mathrm{Ca}$ and $\mathrm{Sr}$, a $15 \mathrm{kV}$ electron beam of $50 \mathrm{nA}$ was used.

$\mathrm{Sr} / \mathrm{Ca}$ ratio profiles were obtained from otoliths of gobies in juvenile to immature adult stages collected by the fish trap, and the translucent larval gobies collected in the surf zone. From the trap we used 3 Stiphodon elegans (Steindachner, 1879) (TL: $22.7 \mathrm{~mm}$, collected on May 2, 1996, TL: 20.3 and $22.9 \mathrm{~mm}$, February 7 and March 27, 1997), 2 Awaous melanocephalus (TL: 34.8 and $53.2 \mathrm{~mm}$, April 26, and June 8, 1996) and only one individual for each of the species, $R$. gigas (TL: $26.8 \mathrm{~mm}$, March 9, 1996) Glossogobius aureus (TL: $68.2 \mathrm{~mm}$, April 30, 1996), Stenogobius genivittatus (Valenciennes, 1837) (TL: $56.8 \mathrm{~mm}$, January 26, 1997), Eleotris fusca (TL: $71.5 \mathrm{~mm}$, May 3, 1996) and Rhinogobius giurinus (Rutter, 1897) (TL: $70.8 \mathrm{~mm}$, June 19, 1995). In addition we used 5 post-larval $R$. gigas (TL: $17-19 \mathrm{~mm}$, April 3, 1997) collected in the surf zone and an adult $R$. gigas (TL: $77.5 \mathrm{~mm}$, November 30, 1995) collected in the upper reaches of the river approximately $70 \mathrm{~km}$ from the river mouth.

After microchemical analysis, the otoliths were polished to remove the carbon coating. Polished otoliths were etched with $8 \%$ EDTA (Ethylenediaminetetraacetate), $\mathrm{pH}=7.4$ or proteinase $\mathrm{K}$ (Shiao et al. 1999) for several minutes, then coated with gold and examined by the scanning electron microscope (HITACHI S2300). In addition to the samples for $\mathrm{Sr} / \mathrm{Ca}$ ratio analysis, more otoliths were prepared for the counting of daily growth increments. The biological and sampling information for the species examined were given in Table 1 and Table 2. An otolith increment was defined as a unit formed by an intact incremental zone and a discontinuous zone outside the core region (Campana and Neilson 1985). The daily growth increments for each otolith were counted three times by the same reader. If the standard deviation for the three readings exceeded $5 \%$, the daily growth increment of the sample was rejected. The mean daily age of $R$. gigas among months was analyzed by one-way ANOVA, with Tukey's pairwise comparison.

\section{Results}

Water temperature at the estuary

Mean water temperature was $23.1^{\circ} \mathrm{C}$ with the lowest water temperature $\left(16.5^{\circ} \mathrm{C}\right)$ occurring in mid-February and the highest temperature $\left(29.3^{\circ} \mathrm{C}\right)$ in August of 1997. Before April, the temperature remained lower than $25^{\circ} \mathrm{C}$ and exceeded $25^{\circ} \mathrm{C}$ for the most of the time after May.

Species composition and periodicities

The upstream migratory gobies collected in the fish trap were early juveniles to immature adults, well pigmented, permitting easy identification. Because the fish trap relies on rheotactic behaviour, only upstream-migrating fish are likely to be caught. R. gigas and S. japonicus predominated in the catch by the fish trap. The major catches of upstream migratory gobies by the fish trap in 1996 occurred between the new and full moons and a minor recruitment occurred around the third quarter of the month (Fig. 3a). The highest daily catches appeared in March and April and the run decreased from May to June. In 1997, the major catches occurred between the full and new moons and the minor recruitment appeared around the second quarter of the month (Fig. 4a). The daily catches of upstream migratory gobies by the fish trap gradually increased from January to March and declined from April to May. Peak daily catches weighed between 10 and $50 \mathrm{~kg}$, with minor peaks between 5 and $10 \mathrm{~kg}$, in 1996 
Table 1 Otolith daily increments (mean \pm S.D.) of Rhinogobius gigas collected by the fish trap at the lower reach and in the surf zone near the mouth of the Hsiukuluan River, eastern Taiwan in 1995. Different letters under the HG (homogeneous group) column indicate a significant difference among the groups (Tukey's pairwise comparison, $p<0.01$ )

\begin{tabular}{|c|c|c|c|c|c|c|c|c|}
\hline 1995 & Total increments & HG & Marine larval duration & HG & Juvenile stage in the estuary & $\mathrm{HG}$ & Total length $(\mathrm{cm})$ & Sample size \\
\hline Febuary 28 & $71.1 \pm 12.1$ & $a$ & $38.3 \pm 5.3$ & $a$ & $32.8 \pm 10.8$ & $a$ & $2.8 \pm 0.2$ & 11 \\
\hline March 23 & $54.8 \pm 10.9$ & $b$ & $37.6 \pm 4.3$ & $a$ & $17.2 \pm 8.6$ & $b$ & $2.9 \pm 0.2$ & 9 \\
\hline April 29 & $48.5 \pm 13.0$ & $b c$ & $35.2 \pm 7.4$ & $a$ & $13.3 \pm 6.8$ & $b$ & $2.2 \pm 0.1$ & 16 \\
\hline May 13 & $43.2 \pm 3.8$ & $c$ & $34.5 \pm 3.4$ & $a$ & $9.1 \pm 3.7$ & $c$ & $2.2 \pm 0.1$ & 18 \\
\hline June 1 & $47.0 \pm 5.8$ & $b c$ & $36.2 \pm 3.9$ & $a$ & $12.2 \pm 5.1$ & $b$ & $2.1 \pm 0.2$ & 20 \\
\hline \multicolumn{9}{|l|}{1997} \\
\hline Febuary 17 & & & $44.5 \pm 2.9$ & $a$ & & & $1.8 \pm 0.1$ & 23 \\
\hline March 26 & & & $46.3 \pm 6.3$ & $a$ & & & $1.7 \pm 0.1$ & 18 \\
\hline April 3 & & & $39.2 \pm 4.2$ & $b$ & & & $1.7 \pm 0.1$ & 17 \\
\hline May 27 & & & $42.7 \pm 4.0$ & $a b$ & & & $1.9 \pm 0.1$ & 15 \\
\hline June 6 & & & $33.7 \pm 3.5$ & $c$ & & & $1.7 \pm 0.1$ & 13 \\
\hline
\end{tabular}

(Fig. 3a) while peak daily catches in 1997 weighed between 10 and $45 \mathrm{~kg}$, with minor peaks between 5 and $15 \mathrm{~kg}$ (Fig. 4a). The total weight of the catch in 1996 was $1069.5 \mathrm{~kg}$ (113 fishing days) and in 1997 was $669.3 \mathrm{~kg}$ (107 fishing days).

During the days with highest catches, the estimated numbers of $S$. japonicus caught in the fish trap ranged from 50,000 to 250,000 in 1996 and from 20,000 to 110,000 in 1997 and decreased to a few thousand on other days (Figs. 3b, 4b). The estimated daily peak numbers of $R$. gigas ranged from 20,000 to 95,000 (1996) and 20,000 to 140,000 (1997) and decreased to a few thousand on other days (Figs. 3c, 4c). The 1996 total catch was about 679,000 for $S$. japonicus and 1,565,000 for $R$. gigas and in 1997 was 1,366,000 and $1,649,000$, respectively. Noticeably, there was no mass upstream migratory population of $R$. gigas in February and March of 1997.

By weight, other species contributed $<1 \%$ of the total biomass. $R$. giurinus and $A$. melanocephalus were the next most abundant species with daily catches reaching numbers of approximately 100 individuals in June 1996 and in March to April 1997. Next, in total (1996-1997), approximately 150-200 individuals each of Eleotris fusca and Glossogobius aureus were collected, and very few Stenogobius genivittatus $(n=3)$, Stiphodon elegans $(n=45)$ and Schismatogobius ampluvinculus (Chen et al. 1995) $(n=39)$ (Fig. 5).
Daily migration

Near low tide, the current velocity at the entrance channel into the sea is fast (about $1 \mathrm{~m} \mathrm{sec}^{-1}$ ) and briefly impedes larval fish from entering the river according to underwater observation by snorkel diving and a CCD video camera at the river mouth. The current velocity slows when the tide rises; in this location post-larval gobies only enter the river during spring high tide period.

The upstream migration of the gobies could be observed from the riverbank when the water was clear. Upstream migratory gobies swam intermittently just above the substrate within areas of current speed between 0.2 and $0.4 \mathrm{~m} \mathrm{sec}^{-1}$. When the current was slow, the gobies migrated in a band around $1 \mathrm{~m}$ wide. When the current was fast, the gobies migrated in a narrower band of 20-30 cm wide similar to the description by Yuma et al. (2000). The migrating speed was about $0.07 \mathrm{~m} \mathrm{sec}^{-1}$ based on the observation of upstream migratory $S$. japonicus across $222 \mathrm{~m}$ in $53 \mathrm{~min}$. Gobies migrated only during daytime, with a peak from noon to evening, suggesting that visual orientation was an essential guide for the upstream-migration behaviors (Fig. 6). Field observations indicated that the gobies at night remained on hard substrate, or in the interstices between stones. The number of gobies collected, in the Amis traditional fish trap (Fig. 2), per 2-h interval ranges from few to over 10,000 (Fig. 6). 


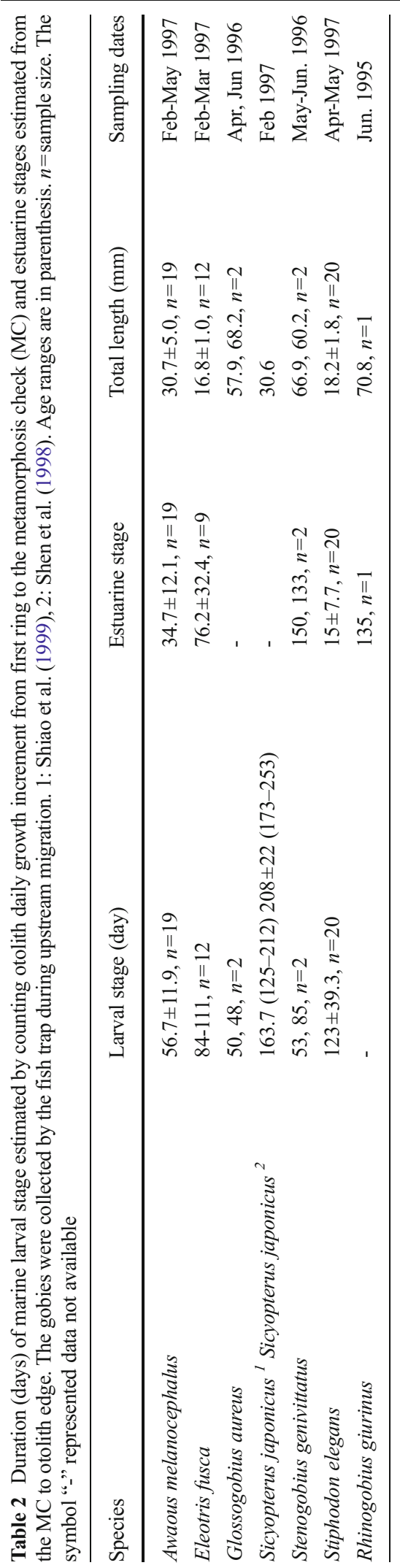

This large variation indicates the episodic character of upstream migration of the gobies as shown in Fig. 3 and Fig. 4.

Otolith growth increment and $\mathrm{Sr} / \mathrm{Ca}$ ratios

The post-marking increments from 18 tetracyclinemarked R. gigas otoliths ranged from 18 to 22 increments (Fig. 7), with a mean value of $19.7 \pm$ 1.03 (mean \pm SD) increments. This was not significantly different from 20 , the number of rearing days, and the experiment is interpreted as confirmation that the increments are daily.

Otolith $\mathrm{Sr} / \mathrm{Ca}$ ratios of seven species' larval stages are shown in Fig. 8. The $\mathrm{Sr} / \mathrm{Ca}$ ratios of the post-larval $R$. gigas collected in the surf zone near the river mouth varied between 4 and $10 \times$ $10^{-3}$ (Fig. 8a). The $\mathrm{Sr} / \mathrm{Ca}$ ratio of an adult $R$. gigas caught at the upper reaches of the river approximately $70 \mathrm{~km}$ from the coast displayed two distinct sections i.e., the values varied between 4 to $9 \times 10^{-3}$ in the inner part of the otolith and the values decreased to 0 to $3 \times 10^{-3}$ at the outer part of the otolith (Fig. 8a). S. elegans showed higher $\mathrm{Sr} / \mathrm{Ca}$ ratios $\left(6\right.$ to $14 \times 10^{-3}$ ) up to $180 \mu \mathrm{m}$ from the core, then the values abruptly drop to below $4 \times 10^{-3}$ (Fig. 8b). G. aureus had large variations of $\mathrm{Sr} / \mathrm{Ca}$ ratios (0 to $\left.16 \times 10^{-3}\right)$ from the otolith core to approximately $250 \mu \mathrm{m}$ then the values remained smaller than $4 \times 10^{-3}$ (Fig. 8c). Similar patterns were also found for S. genivittatus, E. fusca and A. melanocephalus with transition from higher (4 to $17 \times 10^{-3}$ ) to lower $\mathrm{Sr} / \mathrm{Ca}$ ratios $\left(<4 \times 10^{-3}\right)$ at $270 \mu \mathrm{m}$, $200 \mu \mathrm{m}$ and $90 \mu \mathrm{m}$, respectively (Figs. 8b-d). Otolith $\mathrm{Sr} / \mathrm{Ca}$ ratios for $R$. giurinus were different to other species with all values $<4 \times 10^{-3}$ and without any clear transition (Fig. 8d).

A check mark appeared in the otolith of each goby species examined (except $R$. giurinus) when the $\mathrm{Sr} / \mathrm{Ca}$ ratios drop from the marine larval stage to the freshwater stage, indicating transition from the marine larval stage to the river or estuarine stage as shown in Fig. 9a for S. elegans and in Fig. $9 \mathrm{~b}$ for $R$. gigas. The check divided the otolith into higher $\mathrm{Sr} / \mathrm{Ca}$ ratio and lower $\mathrm{Sr} / \mathrm{Ca}$ ratio zones, as illustrated by the $\mathrm{X}$-intensity mapping of $\mathrm{Ca}$ and $\mathrm{Sr}$ concentrations (Fig. 9b). The check was deposited when the gobies entered the 
Fig. 3 The total catch weight (a) and estimated count of migratory gobies (b: Sicyopterus japonicus, c: Rhinogobius gigas) collected by fish trap in the Hsiukuluan River, eastern Taiwan between 22 Feb. and 4 July in 1996. No subsamples were collected before 14 April, 1996 and the species composition is not available. The solid and open cycles indicate the new and full moon, respectively
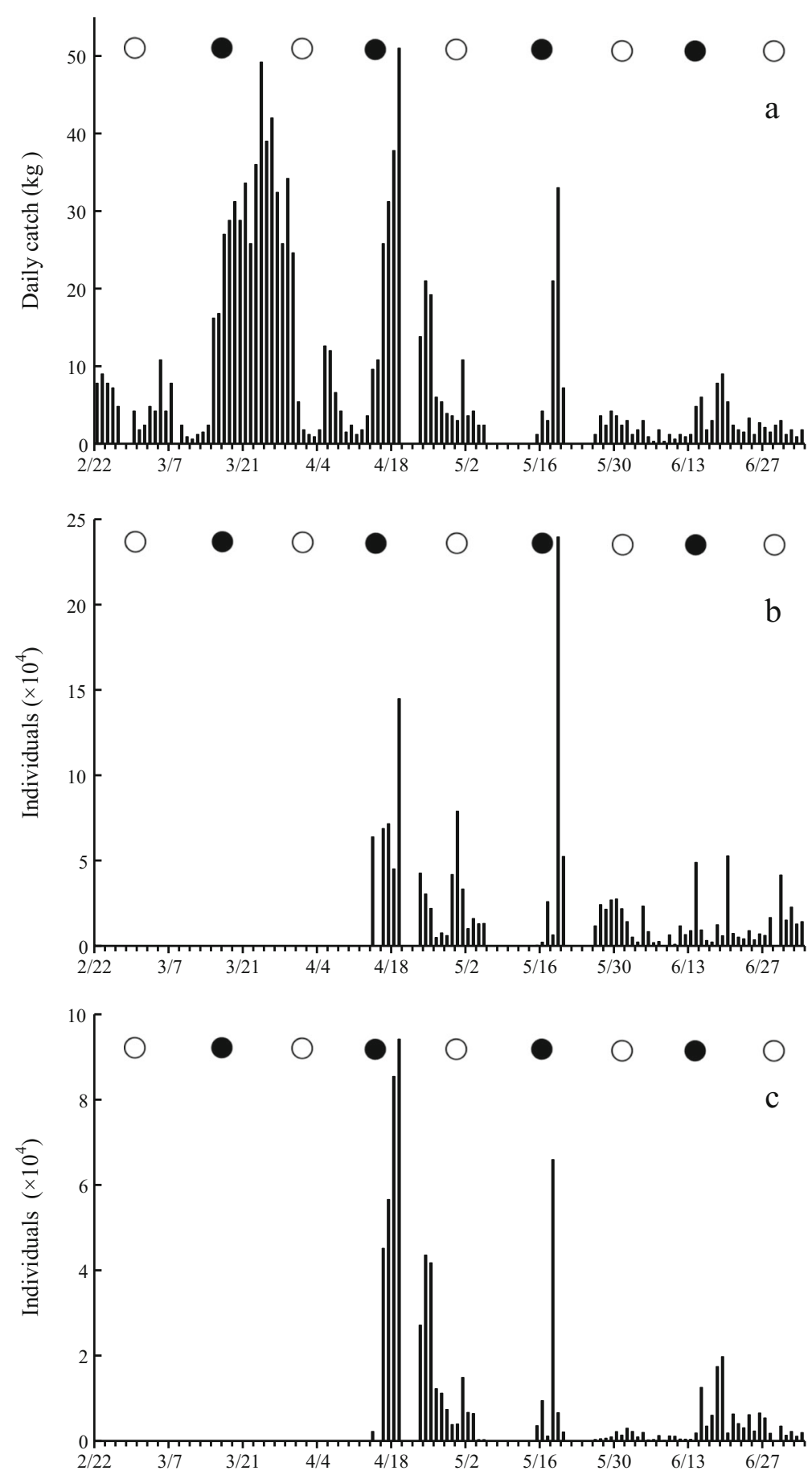

estuary and this discontinuous check was termed a metamorphosis check (Shen and Tzeng 2002; Iida et al. 2008; Taillebois et al. 2012). The increments between the metamorphosis check and the otolith edge were regarded as the estuarine period of the gobies. $R$. gigas had the shortest marine larval stage (around 30-40 days) and an estuarine duration from several days to more than 1 month (Table 1). The marine larval periods were consistent among the sampling 
Fig. 4 The total catch weight (a) and estimated count of migratory gobies (b: Sicyopterus japonicus, c: Rhinogobius gigas) collected by fish trap in the Hsiukuluan River, eastern Taiwan between 30 January and 20 May in 1997. The solid and open cycles indicate the new and full moon, respectively
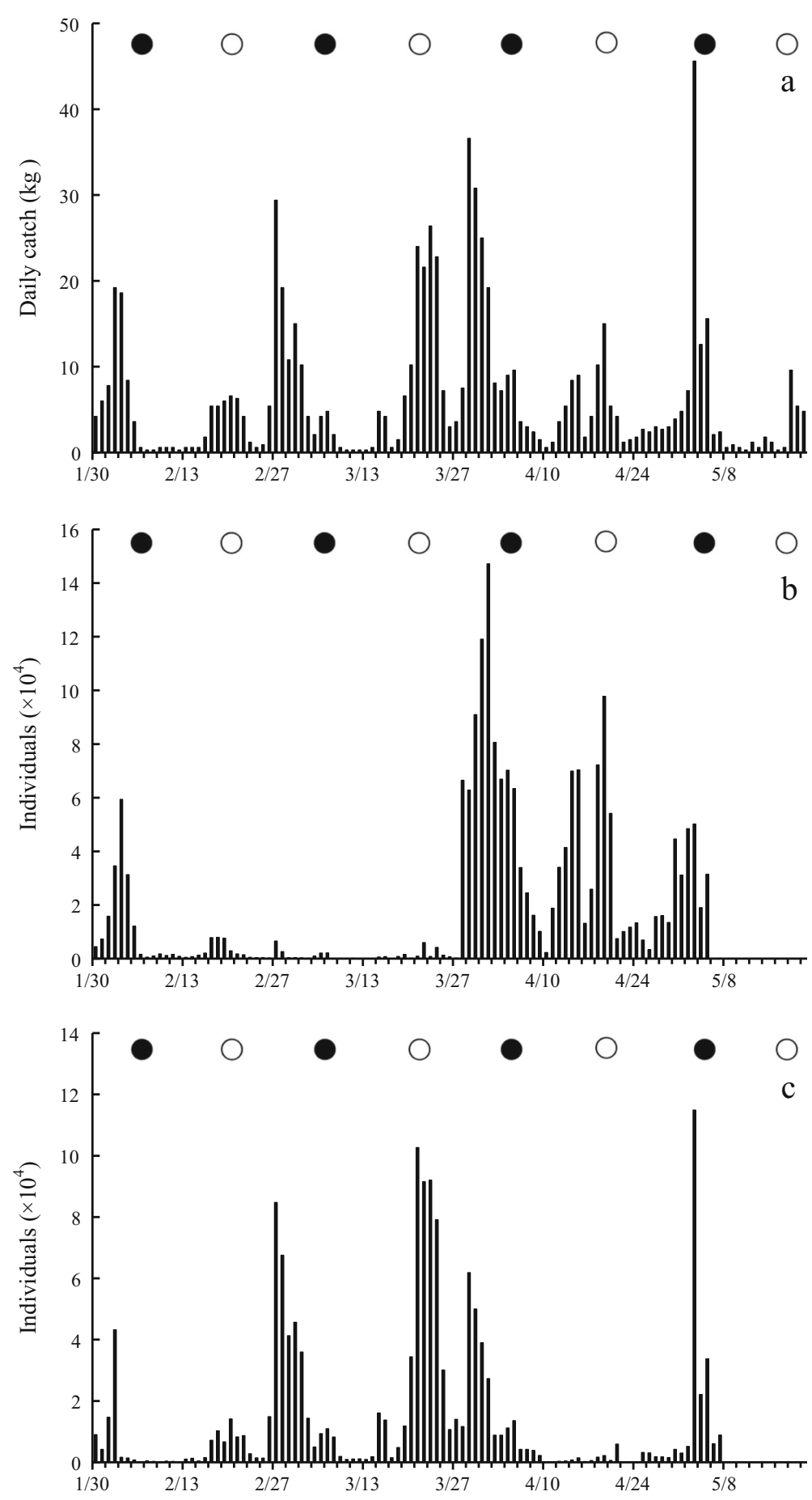

months in 1995, but the marine durations were significantly shorter between April and June in 1997. The estuarine duration of $R$. gigas was also significantly shorter between March and June in the 1995 samples (Tukey's pairwise comparison, $p<0.01$,
Table 1). S. elegans also had a relatively long marine larval stage (123 \pm 39.3 days). The other species e.g., $S$. genivittatus and A. melanocephalus had a marine larval stage of approximately 2-3 months and the longest estuarine duration (1-5 months, Table 2). 
Fig. 5 The numbers of gobies, excluding Rhinogobius gigas and Sicyopterus japonicus, recorded from the fish trap in the Hsiukuluan River, eastern Taiwan in 1996 (a) and 1997 (b)
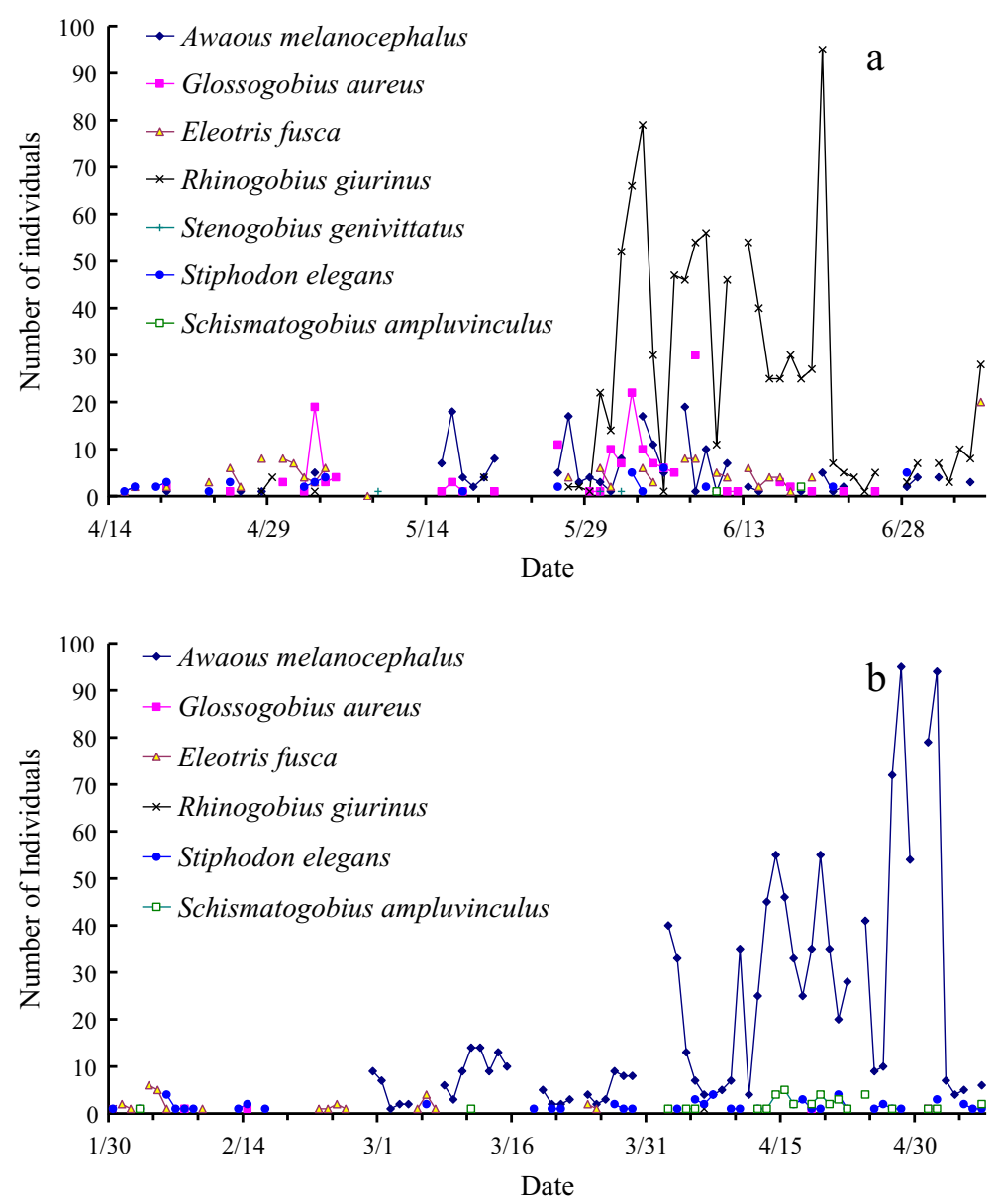

\section{Discussion}

Periodic freshwater recruitment and upstream migration

Fishing for post-larval gobies in the surf zones is a historical culture and activity for the Amis aboriginal people. Fishing activities of the Amis in the surf zone last almost the whole year, with species compositions changing through the cycle. Although we were unable to collect the catch data of the fishermen in the surf zone, our field observations during different months and the interviews with local residents all consistently suggest the seasonal recruitment for the goby species. The postlarval gobies were the main species in the catch from the spring to the summer but very few goby fry if any appear in autumn and winter. During the autumn and the winter, other fish larvae e.g., mullets and Anguilla glass eels are the main species in the catches, which are sold for aquaculture. Local people find the goby fry only near the full moon and new moon. This accords with the synopsis (Bell 1999; Fig. 8 in Bell 2009) of known modal lunar recruitment times and is close to the point identified for the Philippines.

The daily catch data of the fish traps also showed lunar-periodic pattern of upstream migration for the early juvenile gobies. A noteworthy observation was that the migration of the major population at this site, $3 \mathrm{~km}$ upstream of the river mouth, did not correspond to the new moon or full moon precisely, but showed a time lag for several days after the new moon in 1996 and the full moon in 1997. The lag is reasonable and was due to the short stay of the goby fry in the estuary and suggested that most post-larval gobies required 8-10 days to migrate from the estuary to the fish trap. This observation was supported by the data from otolith daily growth increments. The estuarine duration of the goby fry might change among different individuals and species on different 
Fig. 6 The daily migratory patterns of the amphidromous gobies, Rhinogobius gigas and Sicyopterus japonicus, collected at the fish trap in the Hsiukuluan River, eastern Taiwan. Nine day samples were conducted but only data on April 16th (a) and May 7th (b) 1996 are shown for the clarity
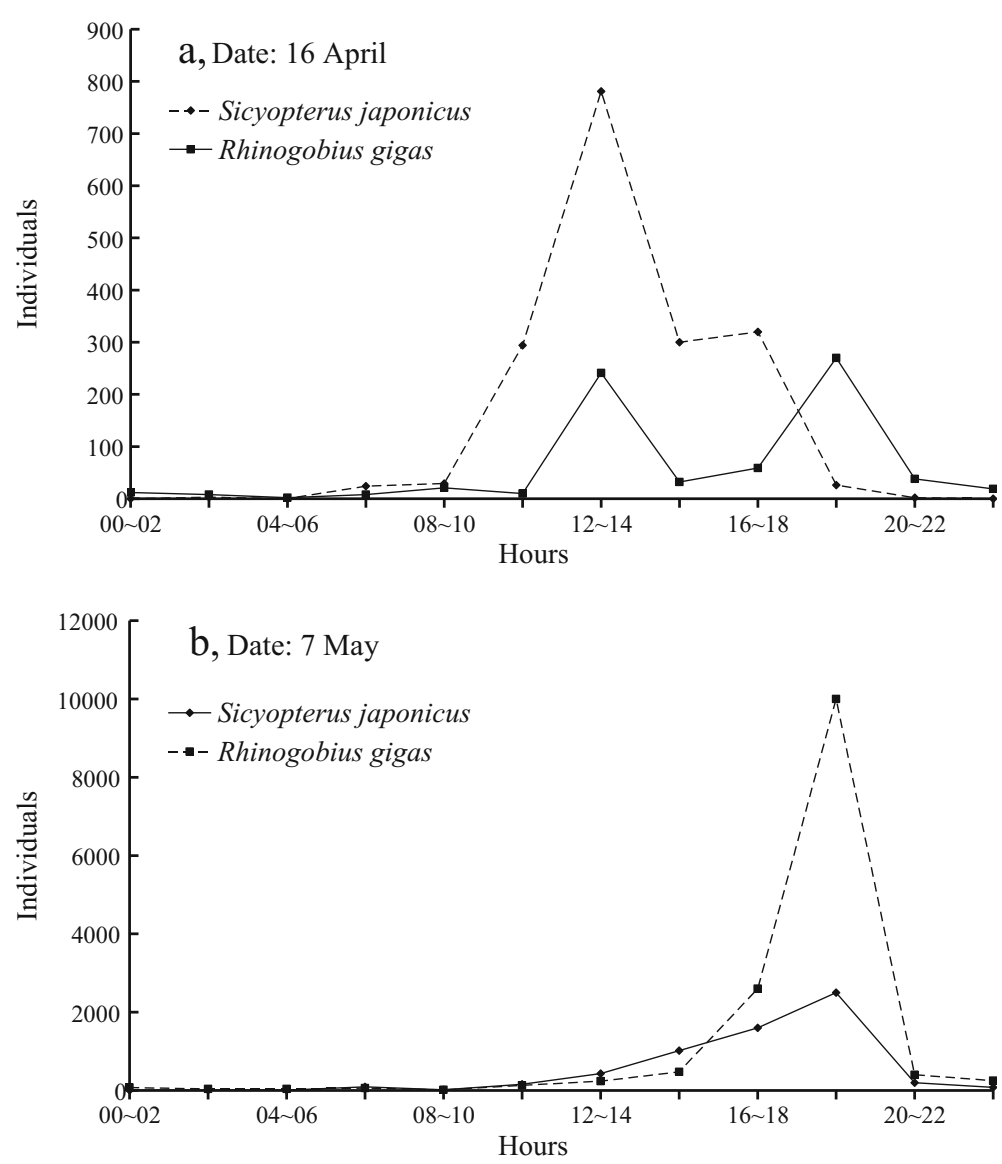

months, as discussed below. In 1997, the first mass upstream migration of $R$. gigas was observed in late January to early February but the migratory populations were very small in February and March. The reasons for the small upstream migratory populations in February to March are not clear but may be due to the failure of spawning events, high larval mortality or some cause for the delay of upstream migration. The mortality during larval drift to the sea is almost unknown for most goby species, except for a few species (Bell 2009). Iguchi and Mizuno (1999) report a high mortality of newly hatched larvae in Rhinogobius brunneus (Temminck and Schlegel, 1845) due to starvation when drifting to sea. Beside, a longer estuarine duration of R. gigas was observed in February and March, 1995. These data support the assumption that $R$. gigas might postpone the upstream migration from the estuary to the upper river to begin only after the water temperature becomes warmer.
Variations of marine larval stage

Daily rings have previously been validated for several goby species, e.g. E. fusca (Maeda et al. 2007), Sicyopterus lagocephalus (Hoareau et al. 2007) and Sicyopus zosterophorum (Bleeker, 1856) (Taillebois et al. 2012). Therefore, as generally found or accepted in the literature, otolith increments were considered to be daily and this valid assumption was applied to the other species whose otoliths were examined in this study. In addition, several goby species have been reported to deposit a check mark in the otolith at the metamorphosis and transition from the marine larval stage to the benthic stage in the estuary (e.g., Shen and Tzeng 2002; Iida et al. 2008; Taillebois et al. 2012). Except for $R$. giurinus, the gobies examined in this study also showed a check mark in the otolith, which corresponded to the drop from higher to lower $\mathrm{Sr} / \mathrm{Ca}$ ratios $\left(<4 \times 10^{-3}\right)$. Therefore, the check mark represented the freshwater recruitment for the amphidromous 


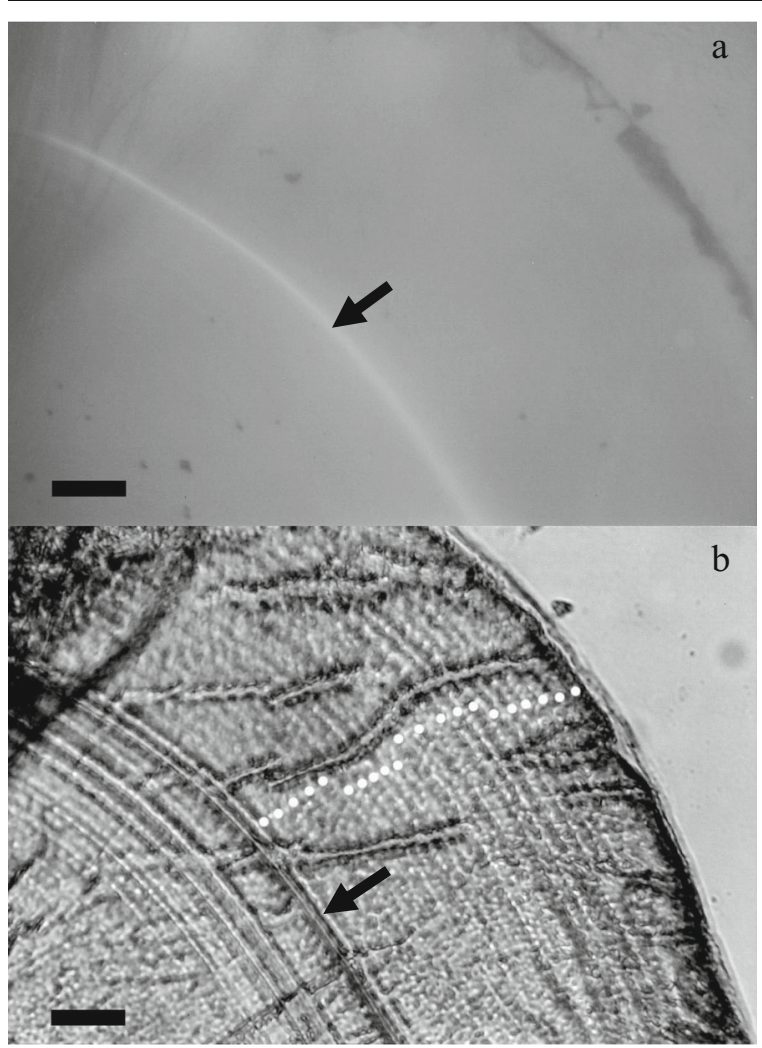

Fig. 7 Otolith of Rhinogobius gigas showing the tetracycline mark (arrow, panel a) and newly deposited daily growth increments (white dots, panel b). The consistency between newly deposited rings and rearing days validates the daily otolith growth increment of the goby. Scale bars $=50 \mu \mathrm{m}$

gobies. In this study, we only analyzed the $\mathrm{Sr} / \mathrm{Ca}$ ratio for a few samples since it was very convenient to define the marine larval stage from the estuarine/river stage by the discernible check mark in the otolith. Only one otolith of $R$. giurinus was analyzed for the $\mathrm{Sr} / \mathrm{Ca}$ ratios and the data suggested a freshwater residence throughout the life. However, more analysis is necessary to clarify the migratory life history of $R$. giurinus since this species is widely distributed in the estuaries, rivers and lakes around Taiwan, southeastern China and Japan. Only a few individuals of $S$. ampluvinculus were collected, but their otoliths were not examined. Although $S$. ampluvinculus was distributed in several rivers of Taiwan and Japan, their life history as amphidromous or freshwater species is still not confirmed (Chen et al. 1995).

Numerous physiological and environmental factors can influence the migratory behaviors of fishes. In this study, water temperature is suspected as one of the regulatory factors affecting the length of the marine stage and the duration of stay within the estuary. The marine larval stage of $R$. gigas was shorter from April to June, 1997 than that in February and March. Similar variations of the marine stage were also reported for the Hawaiian amphidromous goby Lentipes concolor (Radtke et al. 2001) and Eleotris sleepers on Okinawa Island (Maeda et al. 2007), whose planktonic larval stage was shorter during warmer months. After entering the estuary, $R$. gigas and $S$. japonicus gradually developed from translucent post-larvae to pigmented and benthic juveniles. The relatively low water temperature of around $16{ }^{\circ} \mathrm{C}$ in February would cause slow somatic development (Iida et al. 2010). This might be the reason that $R$. gigas post-larval gobies stayed longer in the estuary in February and March of 1995. Higher water temperatures could speed up the morphological transformation and physiological adaption for upstream migration. The shorter estuarine period from March to June 1995 suggested that $R$. gigas might prefer warm water temperatures $>22-24{ }^{\circ} \mathrm{C}$ during upstream migration. In addition, a shorter estuarine stay by $R$. gigas seemed associated with mass migration. Schooling migration has an important antipredator function and is widely observed in amphidromous gobies (e.g., Bell 1999). Therefore, water temperature and migratory biomass may influence the marine larval stage and estuarine stay of amphidromous gobies, although other environmental factors such as seasonal rains cannot be excluded as further influences.

Early life history traits of endemic and widely distributed species

Otolith $\mathrm{Sr} / \mathrm{Ca}$ ratios of $R$. gigas during the oceanic larval stage varied between 4 to $10 \times 10^{-3}$, which was lower than the corresponding values (between 4 to $18 \times 10^{-3}$ ) for other amphidromous gobies. Since the $\mathrm{Sr} / \mathrm{Ca}$ ratio is positively related to the salinity or $\mathrm{Sr}$ concentration in the waters (Zimmerman 2005; Elsdon et al. 2008; Brown and Severin 2009; Lord et al. 2011), the relatively lower otolith $\mathrm{Sr} / \mathrm{Ca}$ ratio suggests that the marine larval stage of $R$. gigas might be distributed inshore near the river plume. Larval retention near the river plume was inferred from stable isotope results of the possible food items for amphidromous Hawaiian gobies (Sorensen and Hobson 2005). Larval retention is an important strategy for endemic species to successfully colonize in insular freshwater habitats, 
Fig. 8 Life-history transects of otolith $\mathrm{Sr}: \mathrm{Ca}$ ratios for amphidromous gobies from the Hsiukuluan River, eastern Taiwan. Panel a: post-larval Rhinogobius gigas caught at the Hsuikuluan River mouth show consistent high $\mathrm{Sr} / \mathrm{Ca}$ ratios and adult $R$. gigas collected in the upper reaches of the river around $70 \mathrm{~km}$ from the coast show higher $\mathrm{Sr} / \mathrm{Ca}$ ratios before $250 \mu \mathrm{m}$ from the core, followed by the lower $\mathrm{Sr} / \mathrm{Ca}$ ratios until the edge. Similar patterns were found in Stiphodon elegans, Awaous melanocephalus, Stenogobius genivittatus, Glossogobius aureus, and Eleotris fusca (panel b-d). Rhinogobius giurinus only shows consistent low $\mathrm{Sr} / \mathrm{Ca}$ ratio $\left(<4 \times 10^{-3}\right)$ from the core the edge (panel d)
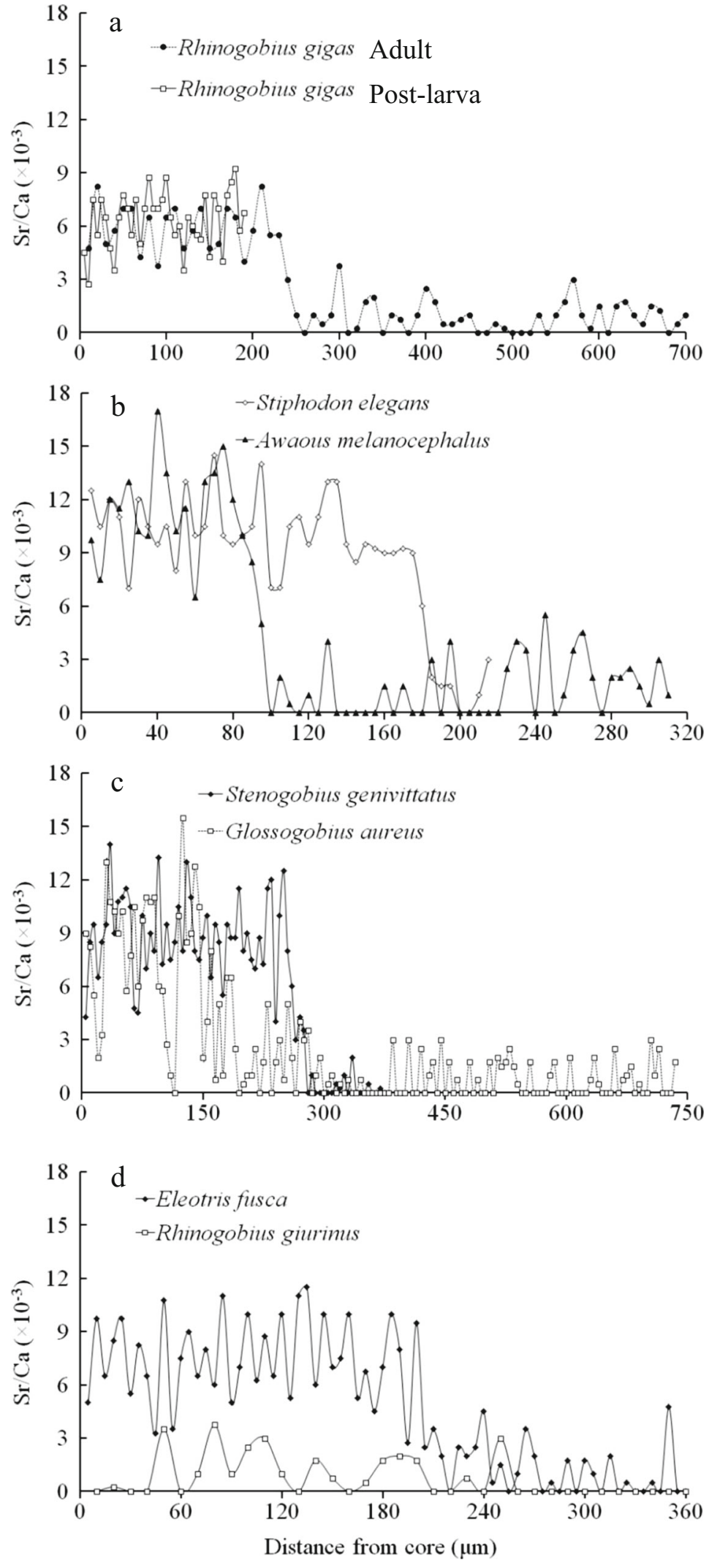


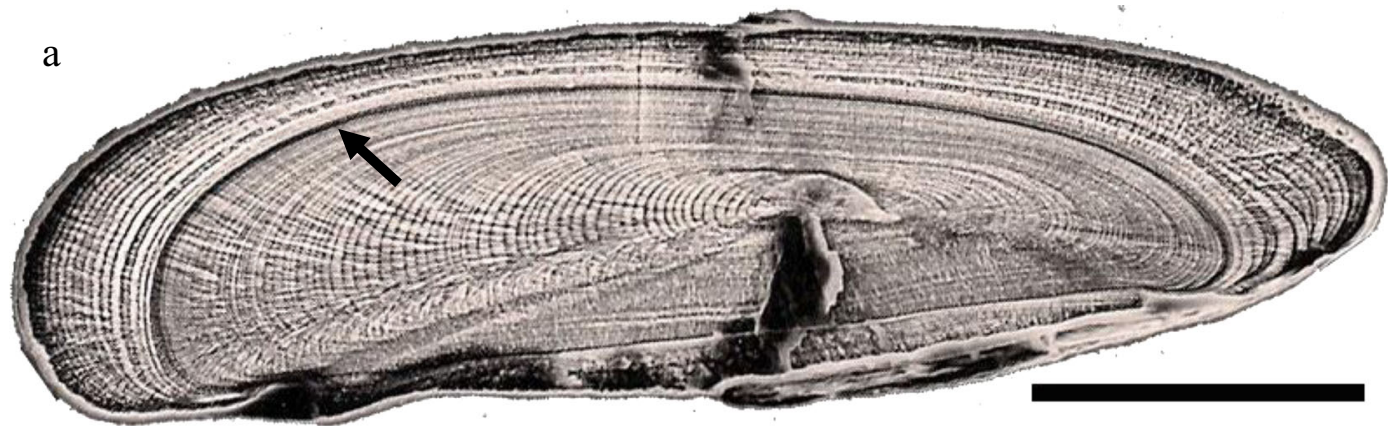

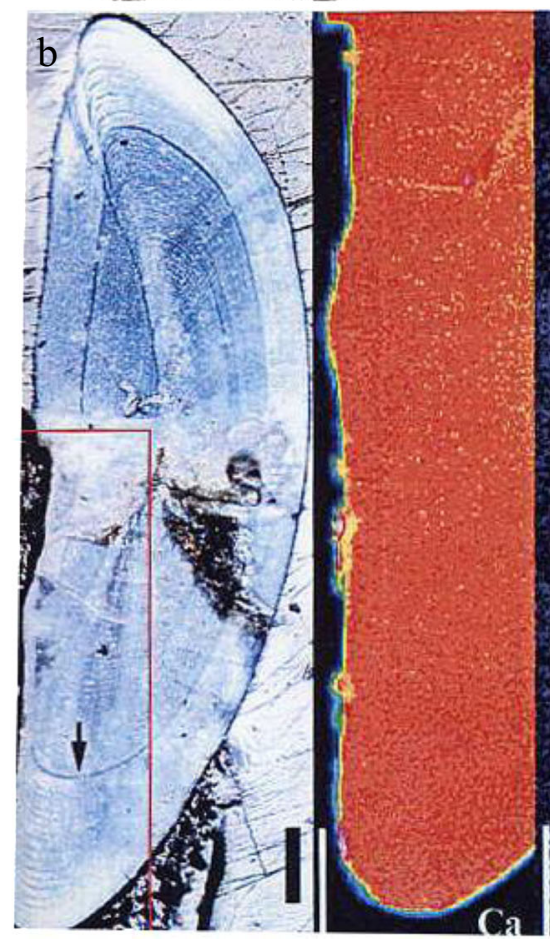

Fig. 9 The otolith microstructure of Stiphodon elegans from the Hsiukuluan River, eastern Taiwan showed a clear daily growth increment and metamorphosis check (panel a). Panel b: X-ray intensity maps of Sr measured within the red-line square marked

especially for the species with a short marine planktonic stage, such as $R$. gigas.

$R$. gigas has the shortest marine larval duration and highest larval growth rate compared to other gobies examined herein or reported in previous studies, for example Sicyopterus japonicus. A short marine stage was also found for species belonging to the same subfamily (Gobionellinae) of $R$. gigas, such as Oligolepis acutipenis (Valenciennes, 1837) and Redigobius bikolanus (Herre, 1927) with only 30-50 days in marine stages (Shen et al. 1998). R. gigas is endemic to the rivers of eastern Taiwan (Aonuma and Chen 1996; Chen

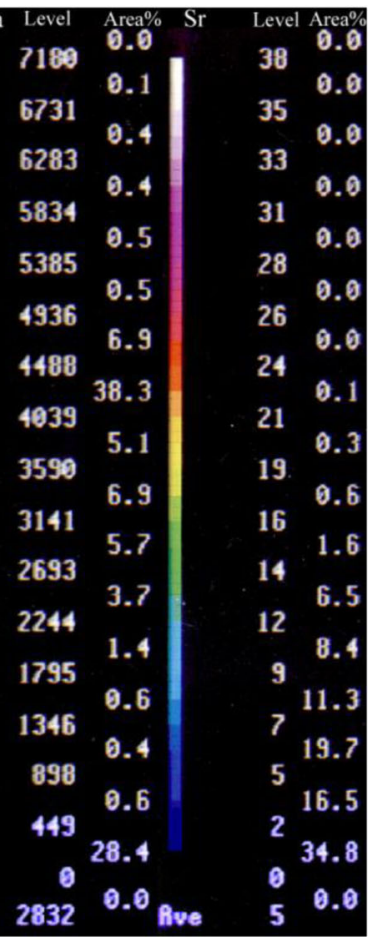

on the otolith from a pigmented juvenile $R$. gigas (TL: $26 \mathrm{~mm}$ ). The light blue region indicates a higher $\mathrm{Sr}$ concentration compared with the deep blue region. The arrows indicate the otolith recruitment check. Bar $=100 \mu \mathrm{m}$ in panel a, and $50 \mu \mathrm{m}$ in panel b

and Shao 1996). The other gobies found in this study are all species with wide distributions in the western Pacific islands. Endemism is believed strongly associated with a short marine larval duration (Lord et al. 2010), with local retention mediated by fish behaviors or ocean currents. Therefore, the short larval stage and local retention near the river plumes are vital life history traits for $R$. gigas survival. However, short marine larval stage is not always a reliable indicator of endemism or the sole factor associated with endemism. Endemic species with longer marine stages can still be found in some islands as well, such as Sicyopterus aiensis (Keith, Watson and Marquet, 2004) in Vanuatu and Sicyopterus sarasini 
(Weber and de Beaufort, 1915) in New Caledonia (Lord et al. 2010). Essential factors leading to endemism are not fully understood, but some plausible explanations have been proposed, such as habitat preferences to avoid high salinity and larval retention in the coastal areas near the estuary (Lord et al. 2010). In contrast, a longer and more variable marine planktonic stage is more suitable for larval dispersion and contributes to the widespread distribution of the adult stage. For example, S. japonicus distributes from Taiwan to Fukushima Prefecture, Japan, has an approximate species range of $2500 \mathrm{~km}$ (Akihito et al. 2000) and has a long and wide-range for the marine larval stage of between 125 and 253 days (Shen et al. 1998; Shiao et al. 1999; Iida et al. 2008).

\section{Life-history traits of dominant species}

In total, nine species of gobies were identified, with> $99 \%$ of the catch being R. gigas and S. japonicus. These two species are dominant in benthic habitats mainly from the middle to the upper reaches of the river (data unpublished). The other goby species, e.g. E. fusca and A. melanocephalus did not show strong upstream migration behaviors and spent a longer period feeding in the estuary (Table 2). Therefore, the spawning biomass should be much larger for $R$. gigas and S. japonicus than other species that had a limited distribution, being confined to the estuary.

High fecundity may be another reason for the dominance of $S$. japonicus. Adult $S$. japonicus of $10.5 \mathrm{~cm}$ in length can produce 225,000 eggs (D tu and Mito 1955) in one reproductive event. We observed S. japonicus of more than $20 \mathrm{~cm}$ in the upper reaches, therefore with even higher fecundity expected. The fecundity of $R$. gigas is still unclear, but may be in a similar range (ca. 1000-5000) of that reported in other species of the genus Rhinogobius (Tamada and Iwata 2005). However, Rhinogobius species can spawn more than once during the breeding season (Takahashi and Yanagisawa 1999), which should lead to higher production of larvae and minimization of the potential for reproductive failure. Based on back-calculation of the daily age at freshwater recruitment, $R$. gigas spawned from December to May and $S$. japonicus spawned from July to December (Shen and Tzeng 2008). The major spawning seasons did not overlap for these two dominant and sympatric species. Furthermore, $R$. gigas is omnivorous and $S$. japonicus is an herbivore feeding on small algae on the stone surface (D tu and Mito 1955; Mochizuki and Fukui 1983). The different spawning seasons and feeding guilds could reduce interspecific competition for nesting sites and food sources. In summary, certain life-history traits of $R$. gigas and S. japonicus, which may include their migratory behavior, fecundity level, non-overlapping spawning season and feeding guilds, as well as their wide distribution in the river may enhance their competition over the other species and subsequently contribute to the dominance of their populations in the rivers.

Acknowledgements We are grateful to the fishermen for their assistance during the field work, and to Mrs Tsai, Department of Material Science, National Tsing Hua University (NTHU) for $\mathrm{Sr}$ and $\mathrm{Ca}$ analysis. This work is partially supported by National Science Council (NSC86-2621-B-007-003-A07) and Council of Agriculture, Republic of China.

\section{References}

Akihito SK, Ikeda Y, Iwata A (2000) Gobioidei. In: Nakabo T (ed) Fishes of Japan with pictorial keys to the species, 2nd edn. Tokai University Press, Tokyo

Aonuma Y, Chen IS (1996) Two new species of Rhinogobius (Teleostei, Gobiidae) from Taiwan. J Taiwan Museum 49: 7-13

Bell KNI (1999) An overview of goby-fry fisheries. Naga Manila 22:30-36

Bell KNI (2009) What comes down must go up: The migration cycle of juvenile-return anadromous taxa. In: Haro AJ, Smith KL, Rulifson RA, Moffitt CM, Klauda RJ, Dadswell MJ, Cunjak RA, Cooper JE, Beal KL, Avery TS (ed) Challenges for Amphidromous Fishes in a Dynamic Global Environment, American Fisheries Society Symposium on Amphidromous Fishes. 69:321-342. Bethesda, Maryland

Bell KNI, Brown JA (1995) Active salinity choice and enhanced swimming endurance in 0 to 8-d-old larvae of amphidromous gobies, including Sicydium punctatum (Pisces), in Dominica, West Indies. Mar Biol 121:409-417

Bell KNI, Pepin P, Brown JA (1995) Seasonal, inverse cycling of length-and age-at-recruitment in the amphidromous gobies Sicydium puntatum and Sicydium antillarum in Dominica, West Indies. Can J Fish Aquat Sci 52:1535-1545

Bielsa S, Francisco P, Mastrorillo S, Parent JP (2003) Seasonal changes of periphytic nutritive quality for Sicyopterus lagocephalus (Pallas, 1770) (Gobiidae) in three streams of Reunion Island. Ann Limnol Int J Lim 39:115-127

Brown RJ, Severin KP (2009) Otolith chemistry analyses indicate that water $\mathrm{Sr}: \mathrm{Ca}$ is the primary factor influencing otolith $\mathrm{Sr}$ : $\mathrm{Ca}$ for freshwater and amphidromous fish but not for marine fish. Can J Fish Aquat Sci 66:1790-1808

Campana SE (2005) Otolith science entering the 21st century. Mar Freshw Res 56:485-495

Campana SE, Neilson JD (1985) Microstructure of fish otoliths. Can J Fish Aquat Sci 42:1014-1032 
Chang CW, lizuka Y (2012) Estuarine use and movement patterns of seven sympatric mugilidae fishes: the tatu creek estuary, central western Taiwan. Estuar Coast Shelf Sci 106:121-126

Chen IS, Shao KT (1996) A taxonomic review of the gobiid fish genus Rhinogobius gill 1859, from Taiwan, with descriptions of three new species. Zool Stud 35:200-214

Chen IS, Shao KT, Fang LS (1995) A new species of freshwater goby Schismatogobius ampluvinculus (Pisces: Gobiidae) from southeastern Taiwan. Zool Stud 34:202-205

D tu Y, Mito S (1955) Life history of the gobioid fish, Sicydium japonicum Tanaka. Science Bulletin of the Faculty of Agriculture, Kyushu University 15:213-221

Elsdon TS, Wells BK, Campana SE, Gillander BM, Jones CM, Limburg KE, Secor DH, Thorrold SR, Walther BD (2008) Otolith chemistry to describe movements and life-history parameters of fishes: hypotheses, assumptions, limitations and inferences. Oceanogr Mar Biol 46:297-330

Foster NR, Fuiman LA (1987) Notes on behavior and early life history of captive lyre gobies, Evorthodus lyricus. B Mar Sci 41:27-35

Gillanders BM (2005) Using elemental chemistry of fish otoliths to determine connectivity between estuarine and coastal habitats. Estuar Coast Shelf Sci 64:47-57

Hoareau T, Lecomte-Finiger R, Grondin HP, Conand C, Berrebi P (2007) Oceanic larval life of La Réunion 'bichiques', amphidromous gobiid post-larvae. Mar Ecol Prog Ser 333: 303-308

Iguchi K, Mizuno N (1999) Early starvation limits survival in amphidromous fishes. J Fish Biol 54:705-712

Iida M, Watanabe S, Shinoda A, Tsukamoto K (2008) Recruitment of the amphidromous goby Sicyopterus japonicus to the estuary of the Ota River, Wakayama, Japan. Environ Biol Fish 83:331-341

Iida M, Watanabe S, Yamada Y, Lord C, Keith P, Tsukamoto K (2010) Survival and behavioral characteristics of amphidromous goby larvae of Sicyopterus japonicus (Tanaka, 1909) during their downstream migration. J Exp Mar Biol Ecol 383:17-22

Keith P, Hoareau TB, Lord C, Ah-Yane O, Gimonneau G, Robinet T, Valade P (2008) Characterisation of post-larval to juvenile stages, metamorphosis and recruitment of an amphidromous goby, Sicyopterus lagocephalus (Pallas) (Teleostei: Gobiidae: Sicydiinae). Mar Freshwater Res 59:876-889

Kinzie RA III (1993) Reproductive biology of an endemic, amphidromous goby Lentipes concolor in Hawaiian streams. Environ Biol Fish 37:257-268

Lord C, Brun C, Hautecoeur M, Keith P (2010) Insights on endemism: comparison of the duration of the marine larval phase estimated by otolith microstructural analysis of three amphidromous Sicyopterus species (Gobioidei: Sicydiinae) from Vanuatu and New Caledonia. Ecol Freshw Fish 19:26-38

Lord C, Tabouret H, Claverie F, Pécheyran C, Keith P (2011) Femtosecond laser ablation ICP-MS measurement of otolith $\mathrm{Sr}: \mathrm{Ca}$ and $\mathrm{Ba}$ Ca composition reveal differential use of freshwater habitats for three amphidromous Sicyopterus (Teleostei: Gobioidei: Sicydiinae) species. J Fish Biol 79: 1304-1321

Maeda K, Yamasaki N, Tachihara K (2007) Size and age at recruitment and spawning season of sleeper, genus Eleotris (teleostei: Eleotridae) on Okinawa island, southern Japan. Raffles B Zool 14:199-207
Maeda K, Yamasaki N, Kondo M, Tachihara K (2008) Reproductive biology and early development of two species of sleeper, Eleotris acanthopoma and Eleotris fusca (Teleostei: Eleotridae). Pac Sci 62:327-340

Manacop PR (1953) The life history and habits of the goby, Sicyopterus extraneus Herre (Anga) gobiidae with an account of the goby-fry fishery of Cagayan River, Oriental Misamis. Philipp J Fish 2:1-58

McDowall RM (2007) On amphidromy a distinct form of diadromy in aquatic organism. Fish 8:1-13

Mochizuki K, Fukui S (1983) Development and replacement of upper jaw teeth in gobiid fish, Sicyopterus japonicus. Jpn J Ichthyol 30:27-36

Myers GS (1949) Usage of anadromous, catadromous and allied terms for migratory fishes. Copeia 1949:89-97

Radtke RL, Kinzie RA, Shafer DJ (2001) Temporal and spatial variation in length of larval life and size at settlement of the Hawaiian amphidromous goby Lentipes concolor. J Fish Biol 59:928-938

Shen KN, Tzeng WN (2002) Formation of a metamorphosis check in otoliths of the amphidromous goby Sicyopterus japonicus. Mar Ecol Prog Ser 228:205-211

Shen KN, Tzeng WN (2008) Reproductive strategy and recruitment dynamics of amphidromous goby Sicyopterus japonicus as revealed by otolith microstructure. J Fish Biol 7:2497-2512

Shen SC, Shao KT, Lee SC, Mok HK, Chen CT, Chen CH (1993) Fishes of Taiwan. National Taiwan University Press, Taipei

Shen KN, Lee YC, Tzeng WN (1998) Use of otolith microchemistry to investigate the life history pattern of gobies in a Taiwanese stream. Zool Stud 37:322329

Shiao JC, Tzeng CS, Leu CL, Chen FC (1999) Enhancing the contrast and visibility of daily growth increments in fish otoliths etched by proteinase K buffer. J Fish Biol 54:302309

Shiao JC, Ložys L, Iizuka Y, Tzeng WN (2006) Migratory patterns and contribution of stocking to the population of European eels Anguilla anguilla by otolith $\mathrm{Sr}$ :Ca ratio analysis. J Fish Biol 69:749-769

Smith RJF, Smith MJ (1998) Rapid acquisition of directional preferences by migratory juveniles of two amphidromous Hawaiian gobies, Awaous guamensis and Sicyopterus stimpsoni. Environ Biol Fish 53:275-282

Sorensen PW, Hobson KA (2005) Stable isotope analysis of amphidromous Hawaiian gobies suggests their larvae spend a substantial period of time in freshwater river plumes. Environ Biol Fish 74:31-42

Tabouret H, Bareille G, Claverie F, Pecheyran C, Prouzet P, Donard OFX (2010) Simultaneous use of strontium: calcium and barium:calcium ratios in otoliths as markers of habitat: application to the European eel (Anguilla anguilla) in the Adour basin, South West France. Mar Environ Res 70:35-45

Taillebois L, Maeda K, Vigne S, Keith P (2012) Pelagic larval duration of three amphidromous Sicydiinae gobies (Teleostei: Gobioidei) including widespread and endemic species. Ecol Freshw Fish 21:552-559

Takahashi D, Yanagisawa Y (1999) Breeding ecology of an amphidromous goby of the genus Rhinogobius. Ichthyol Res 46:185-191 
Tamada K, Iwata K (2005) Intra-specific variations of egg size, clutch size and larval survival related to maternal size in amphidromous Rhinogobius goby. Environ Biol Fish 73: 379-389

Teichert N, Valade P, Fostier A, Lagarde R, Gaudin P (2014) Reproductive biology of an amphidromous goby, Sicyopterus lagocephalus, in La Réunion Island. Hydrobiologia 726:123-141

Tzeng CS (1986a) The freshwater fishes of Taiwan. Press, Taiwan Educational Office
Tzeng CS (1986b) Distribution of the freshwater fishes of Taiwan. J Taiwan Museum 39:127-146

Yuan CR (1969) The Makutaai Ami of eastern Taiwan an ethnographic report. Institute of Ethnology Academia Sinica. 1:193

Yuma M, Maruyama A, Rusuwa B (2000) Behavior and distribution of upstream-migrating juvenile Rhinogobius sp. (the orange form). Ichthyol Res 47:379-384

Zimmerman CE (2005) Relationship of otolith strontium-tocalcium ratios and salinity: experimental validation for juvenile salmonids. Can J Fish Aquat Sci 62:88-97 